\title{
Pengaruh Pemberian Air Perasan Daun Salam (Syzygium polyanthum) dalam Air Minum terhadap Bobot Badan Ayam Broiler
}

\author{
The Effect of Bay Leaf Juice (Syzygium polyanthum) \\ in Drinking Water on Body Weight of Broiler
}

\author{
Sylvina Alzari ${ }^{1 *}$, M. Rekhnin Kamil ${ }^{2}$ \\ ${ }^{1}$ Program Studi Penyuluhan Peternakan dan Kesejahteraan Hewan, \\ Jurusan Peternakan, Politeknik Pembangunan Pertanian Bogor \\ ${ }^{2}$ SMK-PP Negeri Padang Mengatas, Sumatera Barat \\ Korespondensi penulis, E-mail: sylvinaalzari@gmail.com
}

Diterima: Agustus 2021

Disetujui terbit: Desember 2021

\begin{abstract}
Broiler chicken is one type of livestock that is widely consumed to fulfil animal protein needs. Its productivity can be affected by feed. The escalating price of feed is a challenge to provide quality feed at affordable prices. The aim of the study was to analyze the effect of bay leaf juice in drinking water with different levels on body weight and feed conversion ratio (FCR) of broiler. The study was divided into 5 group of treatments regarding on differences in levels of bay leaf juice, such as $P 0=$ control or $0 \%, P 1=5 \%, P 2=10 \%, P 3=15 \%$ and $P 4=20 \%$. Each treatment group consisted of 20 broiler chickens. The variable measured of this study were final body weight, and FCR. The data analysis into descriptive. There was a tendency of increased the average body weight in P1 with $5 \%$ bay leaf juice than other treatments. The FCR in the final showed that in P1 was the lower than other treatments. Utilizing of bay leaf juice in drinking water of broiler has a tendency in increased final body weight and the lower FCR.
\end{abstract}

Keywords: bay leaf juice, body weight, broiler, FCR

\begin{abstract}
ABSTRAK
Ayam broiler merupakan salah satu jenis ternak yang banyak dikembangkan sebagai pemenuhan kebutuhan protein hewani. Produktivitasnya dapat dipengaruhi oleh pakan. Tingginya harga pakan menjadi tantangan tersendiri untuk menyediakan pakan yang bermutu dengan harga terjangkau. Penelitian bertujuan menganalisis pengaruh pemberian ekstrak daun salam pada air minum dengan level yang berbeda terhadap bobot akhir dan FCR ayam broiler. Penelitian dibagi menjadi 5 kelompok perlakuan berdasarkan perbedaan level ekstrak daun salam yaitu P0 = kontrol $0 \%, \mathrm{P} 1=5 \%, \mathrm{P} 2=10 \%, \mathrm{P} 3=15 \%$ dan $\mathrm{P} 4=20 \%$. Masing-masing kelompok perlakuan terdiri atas 20 ekor ayam broiler. Peubah yang diukur dalam penelitian ini adalah bobot badan akhir dan FCR. Data yang diperoleh dianalisis secara deskriptif. Rataan bobot badan P1 dengan perlakuan $5 \%$ perasan daun salam menunjukkan perbedaan bobot badan akhir yang lebih tinggi dibandingkan dengan perlakuan $0 \%, 10 \%, 15 \%$, dan $20 \%$. Hasil penelitian menunjukkan dengan pemberian perasan daun salam sebanyak $5 \%$ dan dapat meningkatkan berat badan ayam broiler dan mendapatkan FCR yang rendah dibandingkan dengan kandang kontrol atau kandang yang lainnya. Hasil penelitian menunjukkan terdapat Penelitian ini membuktikan pemberian $5 \%$ air perasan daun salam dapat meningkatkan kenaikan berat badan broiler dikarenakan memiliki FCR yang rendah dibandingkan dengan kandang lainnya.

Kata kunci: air perasan daun salam, ayam broiler, bobot badan, FCR
\end{abstract}

\section{PENDAHULUAN}

Ayam broiler merupakan salah

satu jenis ternak yang banyak

dikembangkan sebagai sumber pemenuhan kebutuhan protein hewani.

Ayam pedaging ini memiliki

pertumbuhan yang cepat dan hasil

budidaya teknologi maju, sehingga 
memiliki sifat-sifat ekonomi yang menguntungkan. Produktivitas broiler dipengaruhi oleh konsumsi pakan, pertambahan berat badan dan konversi pakan (Septinova et al. 2014).

Pakan merupakan salah satu faktor penting yang memiliki komponen biaya terbesar dalam sistem produksi peternakan broiler. Saat ini tingginya biaya pakan dikarenakan mahalnya harga bahan pakan yang sebagian besar merupakan bahan impor dan masih bersaing dengan kebutuhan manusia. Selain harga pakan yang mahal, tingkat residu komersil yang sangat tinggi untuk mempertahankan imunitas yang baik jauh dari residu pakan maka dilakukan pencampuran pakan dengan bahan pakan tambahan yang memiliki peran sebagai antibiotik. Salah satu contoh bahan campuran yang dapat diberikan adalah jahe merah, kunyit, dan meniran seperti yang dilakukan dalam penelitian Mario et al. (2013). Bahan tambahan lain yang tak kalah menarik untuk digunakan sebagai feed additive adalah daun salam. Daun salam (Eugenia polyantha Wight) adalah produk dari tanaman yang biasanya digunakan sebagai penyedap makanan (Herlina dan Ibrahim 2019).

Daun salam mengandung zat bahan warna, zat samak dan minyak atsiri yang bersifat antibakteri, minyak atsiri $0,2 \%$ (sitral, eugenol), flavonoid (katekin dan rutin), dan metil kavicol (methyl chavicol) yang dikenal juga sebagai estragole atau $p$-allylanisole. Daun salam memiliki kandungan minyak atsiri (euganol) yang mampu meningkatkan palatabilitas ternak (Harismah dan Chusniatun 2016). Herlina dan Ibrahim (2019) melaporkan bahwa penambahan tepung daun salam sebanyak $12 \%$ dalam ransum ayam kampung super meningkatkan konsumsi pakan dan bobot potong. Tanaman salam mempunyai kandungan kimia minyak atsiri 0,2\% (sitral, eugenol), flavonoid (katekin dan rutin), dan metil kavicol (methyl chavicol) yang dikenal juga sebagai estragole atau $p-$ allylanisole. Senyawa tersebut mempunyai aktivitas sebagai antioksidan. Minyak atsiri secara umum mempunyai efek sebagai antimikroba, analgesik, dan meningkatkan kemampuan fagosit.

Minyak atsiri daun salam terdiri dari fenol sederhana, asam fenolat misal asam galat, seskuiterpenoid, dan lakton. Kandungan lainnya adalah saponin, lemak, dan karbohidrat. Beberapa bukti ilmiah menunjukkan bahwa tanaman salam mempunyai efek farmakologis. Pemberian perasan air daun salam pada air minum dapat mensubstitusi probiotik dan vitamin. Efeknya, pemberian air perasan daun salam dapat mengganti pemberian antibiotik 
sehingga bisa meningkatkan pertambahan berat badan ayam broiler.

Berdasarkan hal di atas maka penelitian ini bertujuan untuk mengkaji pengaruh pemberian daun salam (Syzygium polyanthum) sebagai bahan herbal untuk ternak ayam broiler. Metode pengaplikasiannya adalah melalui air minum dengan menambahan ekstrak daun salam.

\section{METODE}

\section{Materi}

Penelitian dilaksanakan di Laboratorium Ternak Unggas SMK-PP Negeri Padang Mengatas selama 28 hari. Peralatan yang digunakan yaitu kandang ayam, tempat pakan polos, tempat minum, kabel listrik, lampu, termometer gantung, gelas ukur, hand sprayer, spayer gendong, timbangan, ember, sapu, tali, alat tulis, alat ukur, gayung, ember, saringan, dan alas kaki khusus untuk di kandang. Bahan yang digunakan adalah broiler PT. Charoen Pokphand galur CP 707 sebanyak 100 ekor, pakan BR 511, sekam padi, kapur, disinfektan, air, dan daun salam.

\section{Persiapan Kandang}

Sanitasi kandang dilakukan dengan pencucian dan penyemprotan kandang menggunakan air bersih dan spayer gendong. Pencucian dan penyemprotan ini bertujuan untuk membersihkan kotoran dan mensterilkan areal kandang bekas pemeliharaan sebelumnya. Selanjutnya kandang diberikan kapur di seluruh lantai dan dinding kandang. Perencanaan untuk kegiatan selanjutnya adalah pemberian disinfektan. Persiapan kandang dan peralatan ini dilakukan dengan tujuan agar kandang yang nantinya digunakan dalam penelitian ini bersih serta bebas dari mikroorganisme penyebab penyakit.

Pemasangan litter dan pemasangan alas berupa serbuk gergaji yang kemudian dilapisi lembaran lembaran koran. Lampu bohlam dinyalakan selama 24 jam sebelum kedatangan anak ayam (day old chick, DOC). Hal ini bertujuan untuk menjaga suhu kandang tetap hangat secara merata sehingga dapat mengurangi angka stress/terkejut karena dingin (cool shock) pada DOC (Tamzil 2014).

\section{Penerimaan DOC}

Setelah DOC tiba, dilakukan penimbangan guna menentukan berat awal DOC. Rataan bobot awal adalah 43,9 g. Setelah ditimbang, DOC dimasukkan ke dalam 5 brooding area berbentuk persegi panjang. Kotak tersebut dapat diperbesar dan diperkecil. Lampu sudah dinyalakan 24 
jam sebelum DOC tiba dengan ketebalan litter $10 \mathrm{~cm}$ serta diberi alas koran 7 lapis di atas serbuk gergaji tersebut dan tiap-tiap brooding diberi termometer dengan suhu awal yaitu 32$33^{\circ} \mathrm{C}$ atau $89-91^{\circ} \mathrm{F}$. Selain itu, dinding pembatas dipasang dengan tinggi 80 $\mathrm{cm}$.

\section{Pembuatan Air Perasan Daun Salam}

Daun salam dipisahkan dari batangnya kemudian dicuci sampai bersih. Selanjutnya daun salam ditimbang sebanyak $1 \mathrm{~kg}$ dan dipersiapkan air bersih sebanyak 5 liter (perbandingan 1:5). Daun salam tersebut dimasukkan ke dalam ember atau wadah dan siapkan air sebanyak 5 liter. Daun salam tersebut dihaluskan dengan menggunakan blender sambal ditambahkan air sedikit demi sedikit. Setelah semua daun salam selesai diblender, daun salam tersebut diperas menggunakan kain bersih atau dengan menggunakan saringan. Air hasil perasan dipisahkan dari ampasnya kemudian masukkan air perasan daun salam dalam wadah tertutup. Air perasan daun salam ini bisa bertahan sampai 5-6 hari setelah proses pembuatannya. Jika lebih dari 5-6 hari, maka perasan air daun salam tersebut akan menimbulkan bau yang tidak sedap dan kemungkinan besar kandungan di dalamnya sudah berubah komposisinya.

\section{Pemberian Pakan dan Air Minum}

Pemberian pakan pada peneitian ini mengikuti pemberian pakan komersil ayam broiler. Pemberian air minum pada minggu ke-1 adalah $200 \mathrm{ml}$ dan mengalami peningkatan pada minggu ke-2 dan ke-3 yaitu $600 \mathrm{ml}$, dan minggu ke-4 sebanyak $1000 \mathrm{ml}$. Jumlah air perasan daun salam yang diberikan diantaranya $\mathrm{PO}=0 \%$ atau $100 \%$ diberikan air putih, $\mathrm{P} 1=5 \%, \mathrm{P} 2=10 \%$, P3 $=15 \%$, dan P4 20\%.

\section{Metode Penelitian}

DOC dibagi menjadi 5 kelompok perlakuan sesuai dengan dosis air perasan daun salam. Sebanyak 100 ekor ayam broiler di bagi menjadi 5 kandang tiap perlakuan. Kandang pertama dijadikan sebagai kandang P0, kandang 2 dijadikan sebagai kandang P1, kandang 3 dijadikan sebagai kandang P2, kandang 4 dijadikan sebagai kandang $\mathrm{P} 3$, dan kandang 5 dijadikan sebagai kandang P4. Peubah yang diukur dalam penelitian ini adalah konsumsi pakan, pertambahan bobot badan harian $(\mathrm{PBBH})$, dan feed conversion ratio (FCR). Data yang didapatkan dari setiap perlakuan diamati dan dianalisis secara deskriptif.

\section{HASIL DAN PEMBAHASAN}


Hasil pengukuran bobot badan ayam broiler setiap minggunya ditunjukkan pada Tabel 1. Berdasarkan hasil penghitungan rataan bobot badan akhir ayam broiler menunjukkan bobot badan masing-masing perlakuan $\mathrm{PO}$, P1, P2, P3, dan P4 berturut-turut adalah 1367,$4 ; 1551,6 ; 1480,4 ; 1527$; dan 1480,2 g. Rataan bobot badan P1 dengan perlakuan $5 \%$ perasan daun salam menunjukkan perbedaan bobot badan akhir yang lebih tinggi dibandingkan dengan perlakuan $0 \%$, $10 \%$, $15 \%$, dan $20 \%$. Gultom et al. (2012) menyatakan bahwa konsumsi konsumsi protein yang rendah menyebabkan bobot potong kecil karena asupan protein untuk pertumbuhan tidak tercukupi sehingga ayam mengalami penghambatan pertumbuhan. Daun salam yang mengandung minyak atsiri, dan flavanoid serta bersifat hipoglikemik flavanoid yang terdapat di dalam daun salam dapat menurunkan kolesterol berarti dapat menurunkan lemak, sehingga daun salam dapat menurunkan lemak, dan persentase daging akan meningkat (Yadnya et al. 2014). Menurut Alfaridz dan Amalia (2018), flavonoid merupakan salah satu metabolit sekunder pada tanaman yang mempunyai sifat antibakteri, antioksidan dan antiinflamasi.

Tabel 1 Hasil pengukuran bobot badan ayam broiler setiap minggu

\begin{tabular}{cccccc}
\hline \multirow{2}{*}{ Minggu ke- } & \multicolumn{5}{c}{ Rataan bobot badan mingguan (g/ekor) } \\
\cline { 2 - 6 } & P0 & P1 & P2 & P3 & P4 \\
\hline 1 & 1366 & 1550 & 1483 & 1530 & 1485 \\
2 & 1370 & 1554 & 1481 & 1532 & 1480 \\
3 & 1368 & 1552 & 1478 & 1525 & 1477 \\
4 & 1367 & 1553 & 1475 & 1522 & 1479 \\
5 & 1366 & 1549 & 1485 & 1526 & 1480 \\
\hline Rata- rata & 1367,4 & 1551,6 & 1480,4 & 1527 & 1480,2 \\
\hline
\end{tabular}

Herlina et al. (2019) menyatakan perlakuan pemberian tepung daun salam tertinggi terdapat pada (P5) sebesar $12 \%$ menghasilkan bobot karkas ayam kampung super tertinggi yaitu rata-rata 570,25 g/ekor. Jadi dapat diambil kesimpulan bahwa pada kotak 2 pertambahan berat badannya naik drastis dibandingkan dengan kandang 1, 3, 4, dan 5. Cara kerja daun salam seperti yang dijelaskan Yadnya et al. (2014) bahwa kandungan minyak atsiri pada daun salam yang bersifat antibakteri yang mampu menghambat pertumbuhan bakteri patogen dalam saluran pencernaan sehingga terjadi peningkatan penyerapan zat-zat makanan dalam tubuh ternak dan proses pembentukan daging menjadi lebih baik. Sehingga pertambahan berat 
badan yang paling baik adalah pada perlakuan 2 dengan pemberian 5\% ekstrak daun salam.

Bobot badan yang berbeda pada setiap perlakuan akan menghasilkan bobot potong yang berbeda pula. Bobot badan yang besar akan menghasilkan bobot potong yang besar dan sebaliknya jika bobot badan yang kecil akan menghasilkan bobot potong yang kecil (Sawadi et al. 2016). Hal ini juga sesuai dengan pendapat Mide (2013) menyatakan bahwa persentase karkas merupakan salah satu faktor penting dalam menilai produksi ternak yang berkaitan erat terhadap bobot hidup, yang dimana semakin meningkat bobot hidup maka bobot karkas juga akan mengalami peningkatan. Selain itu karkas daging ayam broiler ini apabila disimpan dalam waktu yang cukup lama akan mengalami penurunan lama waktu kebusukan. Pura et al. (2015) menjelaskan bahwa kandungan tanin dan flavanoid yang terkandung dalam daun salam dapat menyebabkan terhambatnya pertumbuhan mikroorganisme bahkan kematian.

Perlakuan 5\% ekstrak daun salam menghasilkan berat badan rata-rata yang paling tinggi dibandingkan dengan perlakuan $0 \%, 10 \%, 15 \%$, dan $20 \%$. Hal ini disebabkan oleh kandungan saponin yang tinggi pada daun salam yang jika diberikan dalam jumlah yang banyak maka akan menyebabkan penurunan asupan nutrisi. Hal ini sejalan dengan pendapat Pasaribu (2019) bahwa tanaman lokal banyak mengandung bioaktif seperti obat sehingga penggunaannya harus tepat. $\mathrm{Hal}$ tersebut akan berbeda bila diberikan pada level yang tepat yaitu pada penelitian ini dengan memberikan $5 \%$ ekstrak daun salam yang menghasilkan berat badan yang paling tinggi dan FCR yang paling rendah dibandingkan dengan perlakuan yang lainnya. Magdalena et al. (2013) menyatakan bahwa pemberian saponin pada pakan ternak unggas seperti ayam pedaging diketahui dapat meningkatkan pertumbuhan dan efisiensi pakan, serta meningkatkan kualitas daging ternak, meningkatkan performansi reproduksi ayam pejantan. Selain itu Ningsih et al. (2015) menjelaskan penambahan tepung daun salam (Eugenia polyantha Wight) dalam pakan memberikan pengaruh yang cukup baik terhadap kulaitas fisik daging ayam pedaging yang meliputi nilai $\mathrm{pH}$, keempukan, warna, dan WHC. 
Tabel 2 Hasil penghitungan FCR ayam broiler

\begin{tabular}{cccc}
\hline Perlakuan & Konsumsi pakan (g/ekor) & PBBH (g/ekor) & FCR \\
\hline P0 & 2126 & 1367,4 & 1,55 \\
P1 & 2020 & 1551,5 & 1,30 \\
P2 & 2154 & 1480,4 & 1,45 \\
P3 & 2273 & 1527,0 & 1,48 \\
P4 & 2306 & 1480,2 & 1,55 \\
\hline
\end{tabular}

Keterangan: $\mathrm{P} 0=$ kontro $0 \%$ air perasan daun salam, $\mathrm{P} 1=5 \%, \mathrm{P} 2=10 \%, \mathrm{P} 3=15 \%$ dan $\mathrm{P} 4=20 \%$.

Hasil penghitungan FCR pada ayam broiler yang diberi perlakuan air perasan daun salam dapat dilihat pada Tabel 2. Hasil penelitian menunjukkan dengan pemberian perasan daun salam sebanyak $5 \%$ dan dapat meningkatkan berat badan ayam broiler dan mendapatkan FCR yang rendah dibandingkan dengan kandang kontrol atau kandang yang lainya. Adanya kandungan minyak atsiri dalam daun salam dapat meningkatkan palatabilitas sehingga konsumsi pakan juga akan mengalami peningkatan (Ningsih et al. 2015).

Alasan penggunaan daun salam adalah daun salam memiliki banyak khasiat untuk kesehatan juga mudah didapat. Lebih lanjut Edi (2018) menyatakan bahwa daun salam mengandung flavonoid yang merupakan senyawa fenol yang tergolong dalam senyawa fitokimia yang menjadi substansi antimikroba efektif melawan berbagai macam mikroba patogen. Semakin meningkatnya harga pakan disebut dalam penelitian oleh Narita (2015) bahwa flavonoid mampu menghambat pembentukan micelle usus tempat terjadinya penyerapan asam empedu yang salah satu fungsinya untuk melarutkan lemak melalui saluran empedu ke dalam usus, sehingga dapat meningkatkan penyerapan nutrien pakan.

Hal ini bisa mengurangi konsumsi pakan oleh ayam broiler, sehingga dapat dimanfaatkan sebagai air minum dan pengganti antibiotik (sebagai probiotik). Selain itu, populasi daun salam sangat banyak terutama di Kabupaten Lima Puluh Kota. Pemberian daun salam pada ayam broiler dapat menghambat pertumbuhan bakteri sehingga dapat mencegah terjadinya penyakit pada ayam broiler.Daun salam mengandung ekstrak dengan air yang terdiri atas saponin $95,27 \%$, fenol 40,94 $\mathrm{mg} / \mathrm{g}$, flavonoid $2,78 \mathrm{mg} / 100 \mathrm{~g}$, minyak atsiri $0,2 \%$, dan antioksidan $16,39 \mathrm{mg} / \mathrm{g}$. Kandungan tersebut berperan sebagai antibakteri dan antioksidan sebagai mana hasil penelitian yang dilakukan oleh Harismah dan Chusniatun (2017) serta Sukmasari et al. (2018). Menurut penelitian yang dilakukan oleh Ningsih (2015) pemberian daun salam dalam pakan dapat meningkatkan warna 
kemerahan dan keempukan daging ayam pedaging. Penelitian lainnya yang dilakukan oleh Septinova et al. (2018) menunjukkan bahwa kualitas fisik daging dada dan paha broiler cukup bagus. Selain itu, Yadnya et al. (2014) melaporkan bahwa pemberian tepung daun $+1 \%$ probiotik ditambahkan pada pakan meningkatkan kualitas karkas itik Bali. Hal ini mendukung penelitian yang telah dilakukan karena menunjukkan adanya kecenderungan kenaikan bobot badan dan perbaikan FCR pada tiap konsentrasi ekstrak daun salam, terutama pada dosis pemberian air perasan daun salam sebanyak $5 \%$.

Penelitian pemberian ekstrak daun salam dan tanpa diberi ekstrak daun salam, merupakan penelitian awal dan masih bisa dilanjutkan oleh peternak yang sedang melakukan usaha pemeliharaan ayam broiler ataupun pengusaha ayam broiler dalam skala besar. Menurut Hidayat (2012), salah satu penunjang kemandirian usaha peternakan unggas adalah dengan memanfaatkan bahan pakan lokal. Ketersediaan bahan pakan lokal akan dapat berkelanjutan karena umumnya daerah di Indonesia mempunyai ketersediaan bahan pakan yang belum termanfaatkan secara optimal (Sutanto dan Mulatmi; 2017 dan Sani et al.; 2014). Saat ini baru sekitar $30-40 \%$ dari hasil samping produk pertanian dan perkebunan yang sudah dimanfaatkan sebagai pakan (Edi 2020). Pemanfaatan bahan pakan lokal dapat penunjang kemandirian usaha peternakan unggas dengan cara pembuatan imbuhan pakan dari tanaman lokal.

\section{SIMPULAN}

Pemberian air perasan daun salam sebanyak $5 \%$ melalui air minum menunjukkan kenaikan bobot badan akhir yang lebih tinggi dibandingkan dengan perlakuan $0 \%, 10 \%, 15 \%$, dan $20 \%$.

\section{DAFTAR PUSTAKA}

Alfaridz F, Amalia R. 2018. Review jurnal: klasifikasi dan aktivitas farmakologi dari senyawa aktif flavonoid. Jurnal Farmaka. 16 (3): 1-9.

Edi DN. 2018. Daya hambat mikroba ekstrak daun jati (Tectona grandis linn. F) dan efek penggunaanya dalam pakan ayam petelur. [Tesis]. Malang: Universitas Brawijaya.

Natsir MH, Djunaidi I. 2018. Pengaruh penambahan ekstrak daun jati (Tectona grandis linn. F) dalam pakan terhadap performa ayam petelur. Jurnal Nutrisi Ternak Tropis. 1 (1): 34-44. 
2020. Analysis of regional potency and local feed resources to develop native chicken in East Java Province. Jurnal Ternak. 11 (2): 7-22.

Gultom SM, Supratman H, Abun. 2012. Pengaruh imbangan energi dan protein ransum terhadap bobot karkas dan bobot lemak abdominal ayam broiler umur 3-5 minggu. Student e-Journal. 1 (1): 15-19.

Harismah K, Chusniatun. 2016. Pemanfaatan daun salam (Eugnia polyanta) sebagai obat herbal dan rempah penyedap makanan. Warta LPM. 19 (2): 110-118.

Herlina B, Ibrahim W. 2019. Penambahan tepung daun salam dalam ransum terhadap konsumsi ransum, bobot potong, bobot karkas, dan organ dalam ayam kampung super. Jurnal Sain Peternakan Indonesia. 14(3): 259-262.

Hidayat C. 2012. Pengembangan produksi ayam lokal berbasis bahan pakan lokal. WARTAZOA. 22(2): 85-98.

Magdalena S, Natadiputri GH, Nailufar F, Purwadaria T. 2013. Utilization of natural products as functional feed. Wartazoa Indonesian
Bulletin of Animal and Veterinary Sciences. 23 (1): 31-40.

Mario WLMS, Widodo E, Sjofjan O. 2013. Pengaruh penambahan kombinasi tepung jahe merah, kunyit, dan meniran dalam pakan terhadap kecernaan zat makanan dan energi metabolis ayam pedaging. Jurnal IImu-IImu Peternakan. 24 (1): 1-8.

Mide MZ. 2013. Penampilan broiler yang mendapatkan ransum mengandung tepung daun katuk, rimpang kunyit dan kombinasinya. Jurnal Teknosains. 7 (1): 40-46.

Nazzaro F. Fratianni F, De Martino L, Coppola R, De Feo V. 2013. Effect of essential oils on pathogenic bacteria.

Journal

Pharmaceuticals. 6 (12): 14511474.

Narita EAR. 2015. Bay leaf in dyslipidemia therapy. Jurnal Majority. 4(4): 64-69.

Ningsih N. 2015. Pemanfaatan tepung daun salam (Eugenia Polyantha Wight) dalam pakan terhadap kualitas fisik daging ayam pedaging. [Tesis]. Malang: Universitas Brawijaya. Djunaidi IH, Sjofjan O. 2015. Utilization of salam leaf powder (Eugenia Polyantha Wight) addition in feed on physical 
quality of broiler meat [Theses]. Malang: Universitas Brawijaya.

Pasaribu T. 2019. Peluang zat bioaktif tanaman sebagai alternatif imbuhan pakan antibiotik pada ayam. Jurnal Litbang Pertanian. 38(2): 96-104.

Pura EA, Suradi K, Suryaningsih L. Pengaruh berbagai konsentrasi daun salam (Syzygiumpolyanthum) terhadap daya awet dan akseptabilitas pada karkas ayam broiler. Jurnal IImu Ternak. 15 (2): 33-38.

Sani LOA, Nuraini, Diwan M. 2014. Potensi agribisnis usaha ternak ayam broiler di Kota Kendari. JITRO. 1(1): 88-98.

Sawadi M, Hafid H, Nafiu LO. 2016. Pengaruh bobot potong dan pakan komersial terhadap pertumbuhan ayam broiler. JITRO. 3(3): 47-56.

Septinova D, Hartono M, Santosa PE, Sari SH. 2018. Kualitas fisik daging dada dan paha broiler yang direndam dalam larutan daun salam (Syzygium Polyanthum). Jurnal Ilmiah Peternakan Terpadu. 6(1): 83-88.

Sukmasari S, Mohd FN, Doolaanea AA, Qader OAJA, Rahman MNA. 2018. Total phenolic content, flavonoid content, and antioxidant capacity of Syzygium cumini (L.) skeels leaves grown in Wonosobo, Java, Indonesia and comparison against current findings of Syzygium cumini leaves and Syzygium polyanthum (Wight) Walp leaves. J. Pharm. Sci \& Res. 10 (1): 31-35.

Sutanto A, Mulatmi SNW. 2017. Potensi kelayakan bahan pakan organik untuk ayam kampung di Provinsi Jawa Timur. SENASPRO2. Seminar Nasional dan Gelar Produksi. 608-615.

Tamzil MS. 2014. Stress panas pada unggas: metabolisme, akibat, dan upaya penanggulangannya. WARTAZOA. 24(2): 57-66

Yadnya TGB, Roni NGK, Sukmawati NMS. 2014. Pengaruh pemberian tepung daun salam (Syzygium Polyanthum Walp) dalam ransum yang disuplementasi dengan larutan Effective Microorganisms4 (EM4) melalui air minum terhadap karkas itik bali jantan. Majalah IImiah Peternakan. 17 (1): 30-42.

Yadnya TGB, Witariadi NM, Trisnadewi.AAAS. 2014. Pemanfaatan tepung daun salam (Syzygium Polyanthum Walp), daun pepaya (Carica papaya), atau daun katuk (Sauropus androgynus) dalam ransum yang disuplementasi starpig untuk 
meningkatkan kualitas karkas itik

bali afkir. Majalah IImiah

Peternakan. 17 (2): 66-70. 